\title{
Deletion of tumor suppressors adenomatous polyposis coli and Smad4 in murine luminal epithelial cells causes invasive prostate cancer and loss of androgen receptor expression
}

\author{
Kenneth C. Valkenburg ${ }^{1}$, Angelo M. De Marzo ${ }^{2,3}$, and Bart O. Williams ${ }^{1}$ \\ ${ }^{1}$ Center for Cancer and Cell Biology, Van Andel Research Institute, Grand Rapids, MI 49503, USA \\ ${ }^{2}$ Department of Pathology, Johns Hopkins School of Medicine, Baltimore, MD 21287, USA \\ ${ }^{3}$ Department of Oncology, Johns Hopkins School of Medicine, Baltimore, MD 21287, USA \\ Correspondence to: Kenneth C. Valkenburg, email: kvalken1@jhmi.edu
}

Keywords: mouse model, prostate cancer, basaloid, squamous, Apc

Received: November 01, $2016 \quad$ Accepted: May 03, $2017 \quad$ Published: May 17, 2017

Copyright: Valkenburg et al. This is an open-access article distributed under the terms of the Creative Commons Attribution License 3.0 (CC BY 3.0), which permits unrestricted use, distribution, and reproduction in any medium, provided the original author and source are credited.

\section{ABSTRACT}

Prostate cancer is the most diagnosed non-skin cancer in the US and kills approximately 27,000 men per year in the US. Additional genetic mouse models are needed that recapitulate the heterogeneous nature of human prostate cancer. The Wnt/beta-catenin signaling pathway is important for human prostate tumorigenesis and metastasis, and also drives tumorigenesis in mouse models. Loss of Smad4 has also been found in human prostate cancer and drives tumorigenesis and metastasis when coupled with other genetic aberrations in mouse models. In this work, we concurrently deleted Smad4 and the tumor suppressor and endogenous Wnt/betacatenin inhibitor adenomatous polyposis coli (Apc) in luminal prostate cells in mice. This double conditional knockout model produced invasive castration-resistant prostate carcinoma with no evidence of metastasis. We observed mixed differentiation phenotypes, including basaloid and squamous differentiation. Interestingly, tumor cells in this model commonly lose androgen receptor expression. In addition, tumors disappear in these mice during androgen cycling (castration followed by testosterone reintroduction). These mice model non-metastatic castration resistant prostate cancer and should provide novel information for tumors that have genetic aberrations in the Wnt pathway or Smad4.

\section{INTRODUCTION}

Prostate cancer is the most diagnosed non-skin cancer in men in the United States. Approximately 27,000 men die each year from prostate cancer [1], yet many men survive for years with indolent forms of the disease. Distinguishing indolent from aggressive prostate cancer is a high priority. As such, a need exists for experimental models that recapitulate progression of human prostate cancer. Many molecular signaling pathways are altered in human prostate cancer, meaning that multiple genetic models must exist to ascertain the tumorigenic contributions of these pathways and to generate targeted therapies against them.

Wnt/ $\beta$-catenin pathway activation correlates with prostate cancer progression and metastasis [2]. Notably, a multi-institutional effort to sequence metastatic, castration- resistant prostate cancer found that genomic alterations in the Wnt signaling pathway occur in approximately $18 \%$ of cases, and these included alterations in adenomatous polyposis coli (Apc), an endogenous inhibitor of Wnt signaling [3]. Conditional activation of the $\mathrm{Wnt} / \beta$-catenin pathway in the mouse, either via knockout of Apc $[4,5]$ or constitutive activation of $\beta$-catenin [6,7], causes high grade prostate intraepithelial neoplasia (HGPIN) with infrequent invasiveness. These data indicate that $\mathrm{Wnt} / \beta$ catenin signaling activation alone is sufficient for the development of pre-invasive lesions, but insufficient for progression to invasive or metastatic cancer. A second genetic hit is likely necessary to induce progression [8].

Smad4 is known as the common Smad or Co-Smad because of its necessity in both bone morphogenetic protein (BMP) and transforming growth factor beta 
(TGF $\beta$ ) signaling. Smad4 is a tumor suppressor in prostate tissue [9-11]. Smad4 is deleted in approximately $10 \%$ of prostate cancer cases. It is co-deleted with tumor suppressors phosphatase and tensin homolog (Pten) and p53 approximately $55 \%$ of the time it is mutated [10]. Smad4 loss promotes progression and metastasis in murine prostate cancer models, including conditional Pten and p53 knockouts [10, 12].

The Wnt pathway and Smad4 have been linked in prostate cancer. Oncogenic microRNA miR-1260b targets both Smad4 and secreted frizzled-related protein 1 (sFRP1, an endogenous Wnt pathway inhibitor) [13], suggesting that there is a population of prostate cancer patients in which the Wnt pathway is up-regulated while the BMP and TGF $\beta$ pathways are inactivated. Another study showed that Wnt3a-neutralizing antibodies reversed tumorigenesis caused by the stromal-specific knockout of TGF $\beta$ receptor II, which is frequently lost in human prostate cancer [14].

Because of these data, we created a genetically engineered mouse model in which Apc and Smad4 were concurrently deleted in prostate luminal cells, using the $N k x 3.1$ gene promoter to drive tamoxifen-inducible Cre recombinase expression [15]. We and others have shown that $N k x 3.1^{\text {CreERT }}$ is active in the luminal cell population of the adult murine prostate $[5,15]$. We show here that loss of both Apc and Smad4 results in invasive, castrationresistant prostate carcinoma with androgen receptor (AR) loss. Notably, this phenotype disappeared upon hormonal regeneration following castration.

\section{RESULTS}

\section{Apc - Smad4 double knockout mouse model}

Smad4 protein levels in wild-type prostate tissue are relatively low, but when the tumor suppressor phosphatase and tensin homolog (Pten) is lost, Smad4 levels increase, suggesting that Smad4 acts to constrain tumor progression [10]. To determine whether Smad4 levels would also increase in a Wnt/ $\beta$-catenin-driven tumor model using

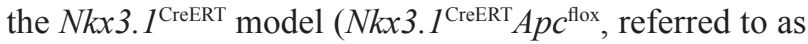
$\left.\mathrm{Apc}^{\mathrm{cKO}}[5]\right)$, we performed Smad4 immunohistochemistry (IHC) and quantitative reverse transcriptase PCR (qPCR) on Cre-negative $\left(\mathrm{Apc}^{\mathrm{flox}}\right)$ and Cre-positive $\left(\mathrm{Apc}^{\mathrm{cKO}}\right)$ prostate tissue. Smad4 protein and RNA levels increased in $\mathrm{Apc}^{\mathrm{cKO}}$ mice relative to the $\mathrm{Apc} \mathrm{c}^{\text {flox }}$ control (Figure 1A-1B). Axin2 expression also increases upon Apc loss as expected, and served as a positive control (Figure 1B). We concluded from these data that Smad4 might be constraining tumor progression in $\mathrm{Apc}^{\mathrm{cKO}}$ mice, which display high-grade prostate intraepithelial neoplasia (HGPIN) but infrequent invasion and no evidence of metastasis [5]. Therefore, we crossed $\mathrm{Apc}^{\mathrm{cKO}}$ mice to Smad4 ${ }^{\text {flox }}$ mice, a generous gift from Ronald DePinho (MD Anderson Cancer Center) [16]. We will refer to these $N k x 3.1^{\text {CreERT }} A p c^{\text {flox }} S m a d 4^{\text {flox }}$ double knockout mice as $\mathrm{Apc}^{\mathrm{cKO}} \mathrm{Smad} 4{ }^{\mathrm{cKO}}$, in which both the Apc and Smad4 genes have been deleted in the prostate. It is important to note that the Cre driver we used $\left(N k \times 3.1^{\text {CreERT }}\right)$ is tamoxifen-inducible, meaning that Cre recombinase is not active until mice are treated with tamoxifen; we treated 3-month-old mice once per day for two consecutive days via oral gavage to activate Cre (Figure 1C) [5]. We used Cre-negative mice bearing the Apc and Smad4 floxed alleles as controls, and we will refer to them as $\mathrm{Apc}{ }^{\text {flox }} \mathrm{Smad} 4{ }^{\text {flox }}$ mice. We also treated these control mice with tamoxifen; the only thing lacking in the control mice was Cre recombinase. We have previously shown that treating $N k x 3.1^{\mathrm{CreERT}} A p c^{\text {wild-type }}$ mice with tamoxifen showed no overt phenotype [5]. Using allele-specific PCR we determined that in addition to Apc recombination [5], we were able to induce Smad4 recombination in prostate tissue (Figure 1D). Genetic recombination did not occur in lung, liver, lymph node, or testis (data not shown), but did occur in the bulbourethral gland (Figure 1D). This is due to $\mathrm{Nkx3} .1$ expression in the bulbourethral gland (BUG) as previously reported $[4,17]$.

\section{Invasive carcinoma in $\mathrm{Apc}^{c K O} \mathrm{Smad} 4^{c K O}$ mice}

We euthanized $\mathrm{Apc} \mathrm{cKO}^{\mathrm{KO}} \mathrm{Smad} 4^{\mathrm{cKO}}$ mice at 7 months of age and observed large tumors in the anterior prostate lobes in $72 \%(13 / 18)$ of the mice (Figure $2 \mathrm{~A})$. It is possible that some of the mice did not get tumors due to a mixed genetic background (Supplementary Table 1). No overt tumors were grossly apparent in $\mathrm{Apc}^{\mathrm{cKO}}$ or Smad4 ${ }^{\mathrm{cKO}}$ prostates, as previously observed (although $\mathrm{Apc}^{\mathrm{cKO}}$ mice did develop high-grade prostate intraepithelial neoplasia (HGPIN)) $[5,10]$. Smad4 ${ }^{\mathrm{CKO}}$ prostate tissue displayed no histological evidence of neoplasia (Supplementary Figure 3).

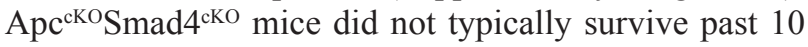
months of age due to large tumors in their abdomen, which originated from the BUG (Supplementary Figure 2A).

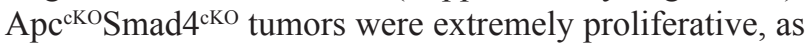
evidenced by a statistically significant rise in Ki67 staining relative to $\mathrm{Apc}^{\text {flox }} \mathrm{Smad} 4^{\text {flox }}$ control tissue or $\mathrm{Apc}^{\mathrm{cKO}}$ tumors (Figure 2B-2C).

Further histological analysis revealed that $\mathrm{Apc}^{\mathrm{cKO} S m a d 4}{ }^{\mathrm{cKO}}$ tumors displayed a range of differentiation phenotypes. We observed large regions of squamous differentiation with keratohyalin granule formation and loss of nuclei (Figure 3). As expected, cytoplasmic and nuclear $\beta$-catenin levels remained low in $\mathrm{Apc}^{\text {flox }}{ }^{\mathrm{Smad}} 4^{\text {flox }}$ prostate tissue but rose in the basal cell compartment of Apc ${ }^{\mathrm{cKO} S m a d} 4{ }^{\mathrm{cKO}}$ malignant prostate tissue (Figure 3). The gain of nuclear and cytoplasmic $\beta$-catenin and loss of Smad4 directly correlated to increased levels of proliferation markers Ki67 and cyclin D1 (Figure 3). The bulbourethral glands from $\mathrm{Apc}^{\mathrm{cKO} S m a d 4}{ }^{\mathrm{cKO}}$ mice also displayed invasive carcinoma, increased $\beta$-catenin signaling, and high levels of 
proliferation (Supplementary Figure 2B). Interestingly, we observed a loss of AR expression in malignant prostate tissue (Figure 4). Changes in AR expression have not been linked to loss of Apc or Smad4 previously. We also assessed expression of luminal cell marker cytokeratin 8 (CK8) and basal cell markers cytokeratin 14 (CK14) and p63. Malignant prostate tissue lost CK8 expression and gained CK14 and p63 expression (Figure 4). p63 expression was located largely in the basal cell layer in $\mathrm{Apc}^{\text {flox }} \mathrm{Smad} 4^{\text {flox }}$ mice, but expanded significantly in $\mathrm{Apc}^{\mathrm{cKO}} \mathrm{Smad} 4{ }^{\mathrm{cKO}}$ mice (Figure 4).
In addition to squamous differentiation, we also observed carcinoma with a basaloid appearance and cribriform architecture (Figure 5). We observed invasion of both basaloid and squamous carcinomas into the muscle layer (Figure 5C-5D). Figure 5F shows a region of both differentiation phenotypes in the same small region of a tumor. While $\beta$-catenin and Ki67 staining was localized to the basal layer in squamous regions (Figure 3), basaloid regions had pervasive $\beta$-catenin and $\mathrm{Ki} 67$ staining patterns, more similar to what was seen in the $\mathrm{Apc}^{\mathrm{cKO}}$ model (Figure 5G-5H).
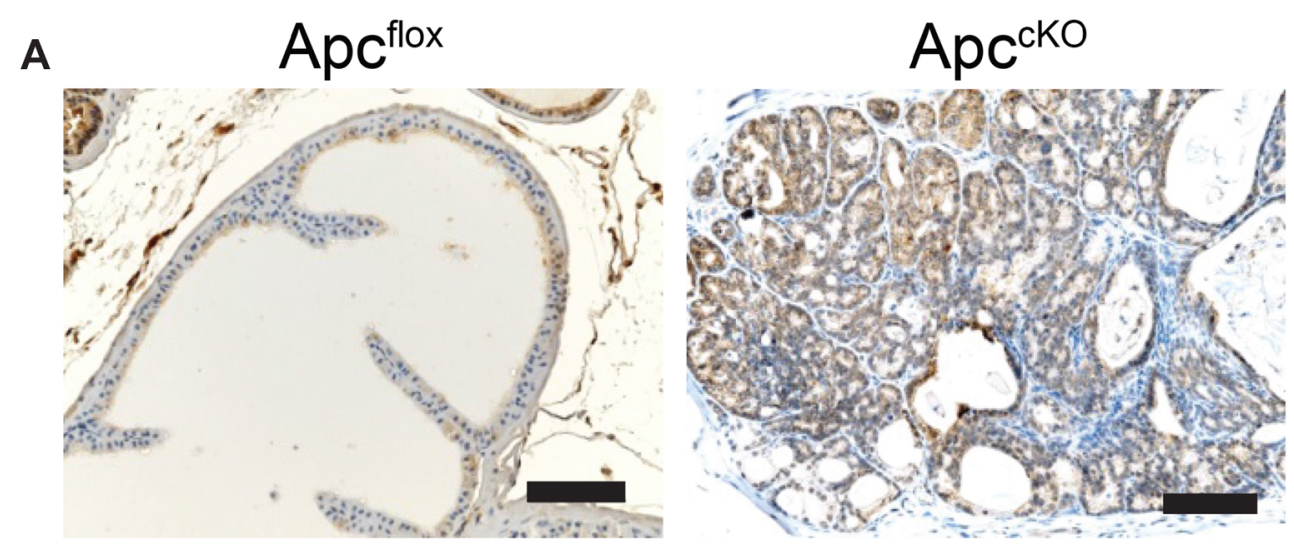

B

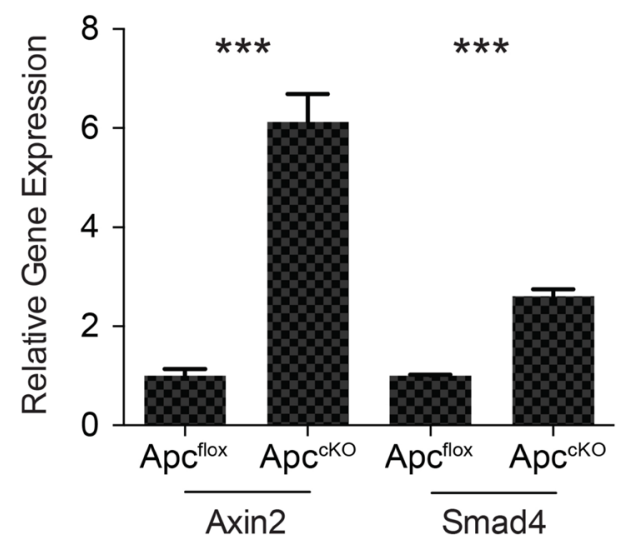

C

Months

1

2

3

$\Delta$

Birth

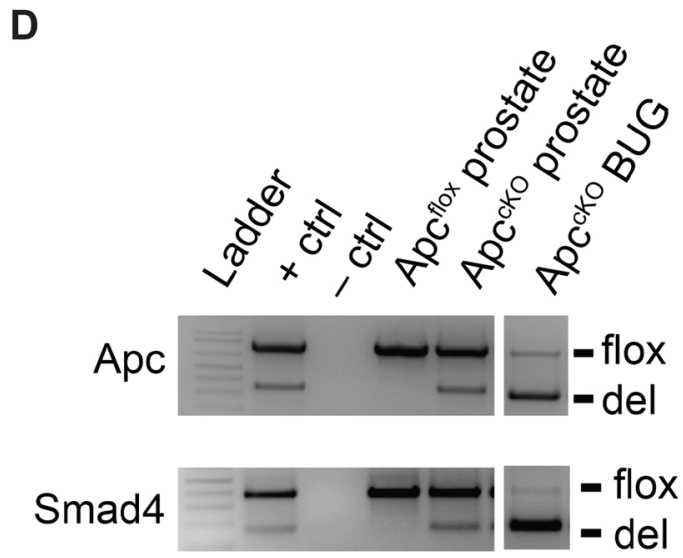

$\begin{array}{lll}4 & 5 & 6\end{array}$

7

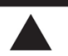

Analysis

\section{Androgens Present}

Figure 1: Rationale behind the Apc-Smad4 double knockout (Apc ${ }^{\text {cKoSmad4 }}{ }^{\text {cKo }}$ ) mouse model. (A) Smad4 immuno-staining on prostate tissue from Apc ${ }^{\text {flox }}$ and $\mathrm{Apc}^{\mathrm{cKO}}$ mice (scale bars $\left.=100 \mu \mathrm{m}\right) ;(\mathbf{B})$ Axin2 and Smad4 quantitative reverse-transcriptase PCR from $\mathrm{Apc}^{\mathrm{flox}}$ and $\mathrm{Apc} \mathrm{cKO}^{\mathrm{KO}}$ prostate tissue (error bars represent standard deviation based on technical triplicates; $* * * P$ value $\left.<1 \times 10^{-4}\right)$; $(\mathbf{D})$ allelespecific PCR for Apc and Smad4 showing the floxed band (flox) and the band as a result of deletion (del) in prostate and bulbourethral gland tissue; and $(\mathbf{C})$ timeline of tamoxifen administration and sacrifice of control and experimental mice. 
Interestingly, Smad4 ${ }^{\mathrm{cKO}}$ prostate tissue displayed normal features when stained for $\beta$-catenin, Ki67, CK8, CK14, cyclin D1, and AR (Supplementary Figure 3), indicating that loss of both tumor suppressors is required to cause this observed phenotype. These data indicate that deletion of Apc and Smad4 are indeed the driving forces behind the carcinomatoid phenotype observed in these mice.

\section{Tumors in $\mathrm{Apc}^{c K O} \mathrm{Smad}^{c K O}$ mice are castration resistant}

To test the ability of $\mathrm{Apc}^{\mathrm{cKO}} \mathrm{Smad} 4{ }^{\mathrm{cKO}}$ prostate tumors to grow under castration conditions, we treated mice with tamoxifen at 3 months of age, and then castrated them 3 months later, after tumors had presumptively formed (Figure 6A). Tumors shrunk

A
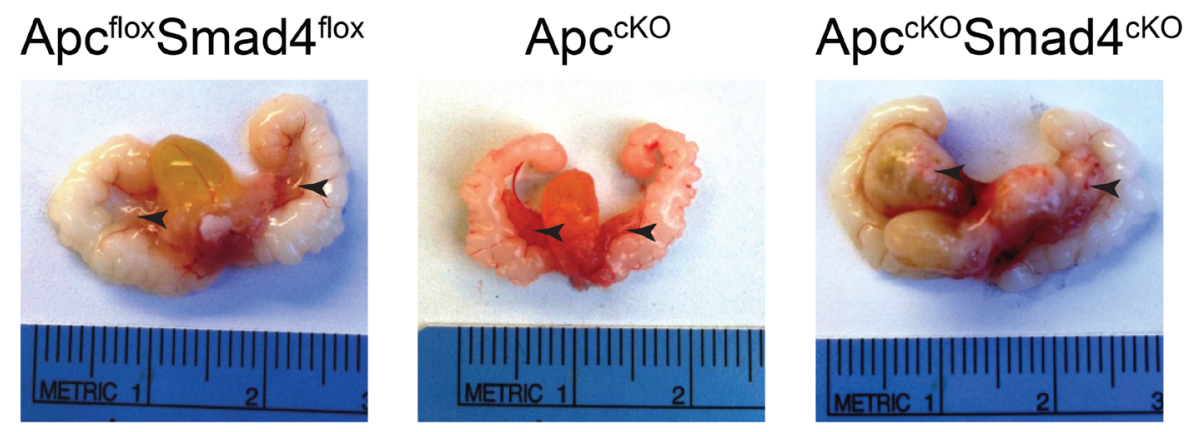

B
H\&E
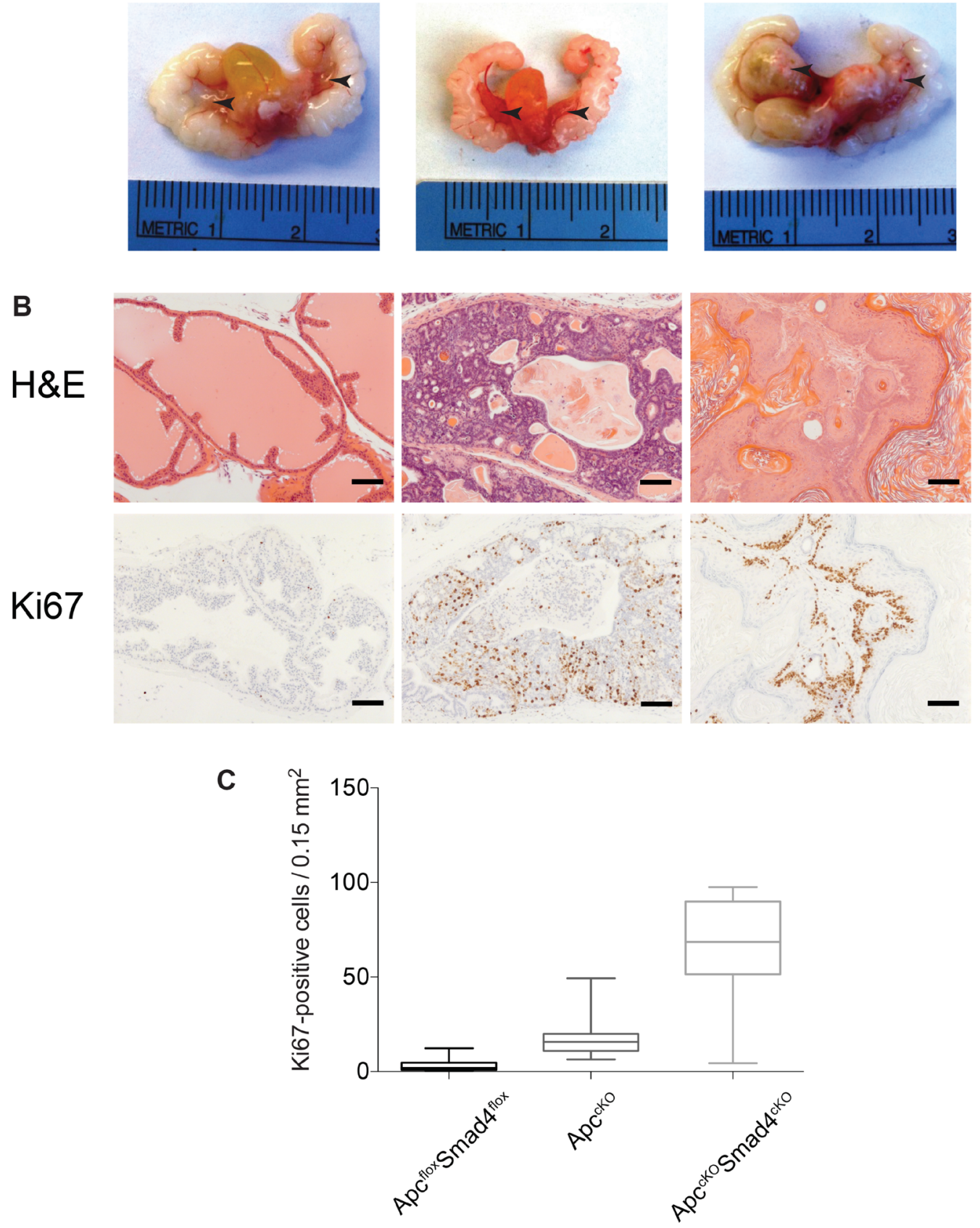

Figure 2: Proliferative increases in Apc ${ }^{\mathrm{cKO}} \mathrm{Smad}^{\mathrm{cKO}}$ mice compared to Apc ${ }^{\mathrm{cKO}}$ mice. (A) Urogenital tracts, including prostate tissue, from $\mathrm{Apc}^{\mathrm{flox}} \mathrm{Smad} 4^{\mathrm{flox}}, \mathrm{Apc}^{\mathrm{cKO}}$, and $\mathrm{Apc}{ }^{\mathrm{cKO}} \mathrm{Smad} 44^{\mathrm{cKO}}$ mice (arrows indicate the anterior prostate lobes); (B) H\&E staining and Ki67 immuno-staining of prostate tissues (scale bars $=100 \mu \mathrm{m}$ ); and $(\mathbf{C})$ Nuance microscope quantification of proliferating (Ki67-positive) cells in prostate cells from $\mathrm{Apc}^{\text {flox }} \mathrm{Smad}_{4}^{\text {flox }}, \mathrm{Apc}^{\mathrm{cKO}}$, and $\mathrm{Apc}^{\mathrm{cKO}} \mathrm{Smad} 4{ }^{\mathrm{cKO}}$ mice. For all groups, $P$ value $<1.0 \times 10^{-12}$. 
moderately after castration but retained regions of nuclear $\beta$-catenin and Ki67 staining, indicating castration resistance (Figure 6B). The same phenotype was present in the BUGs in $\mathrm{Apc}^{\mathrm{cKO}} \mathrm{Smad} 4^{\mathrm{cKO}}$ mice (Supplementary Figure 2C). When we castrated before tamoxifen administration, tumors did not form in the prostate or $\mathrm{BUG}$, indicating that androgens are required for tumor development but not for tumor maintenance (data not shown). We had previously observed a similar phenotype in the $A p c^{\mathrm{cKO}}$ mice [4].

\section{Androgen cycling eliminates the carcinoma phenotype}

Wang et al. showed that a cycle of castration and testosterone reintroduction expanded the castration-

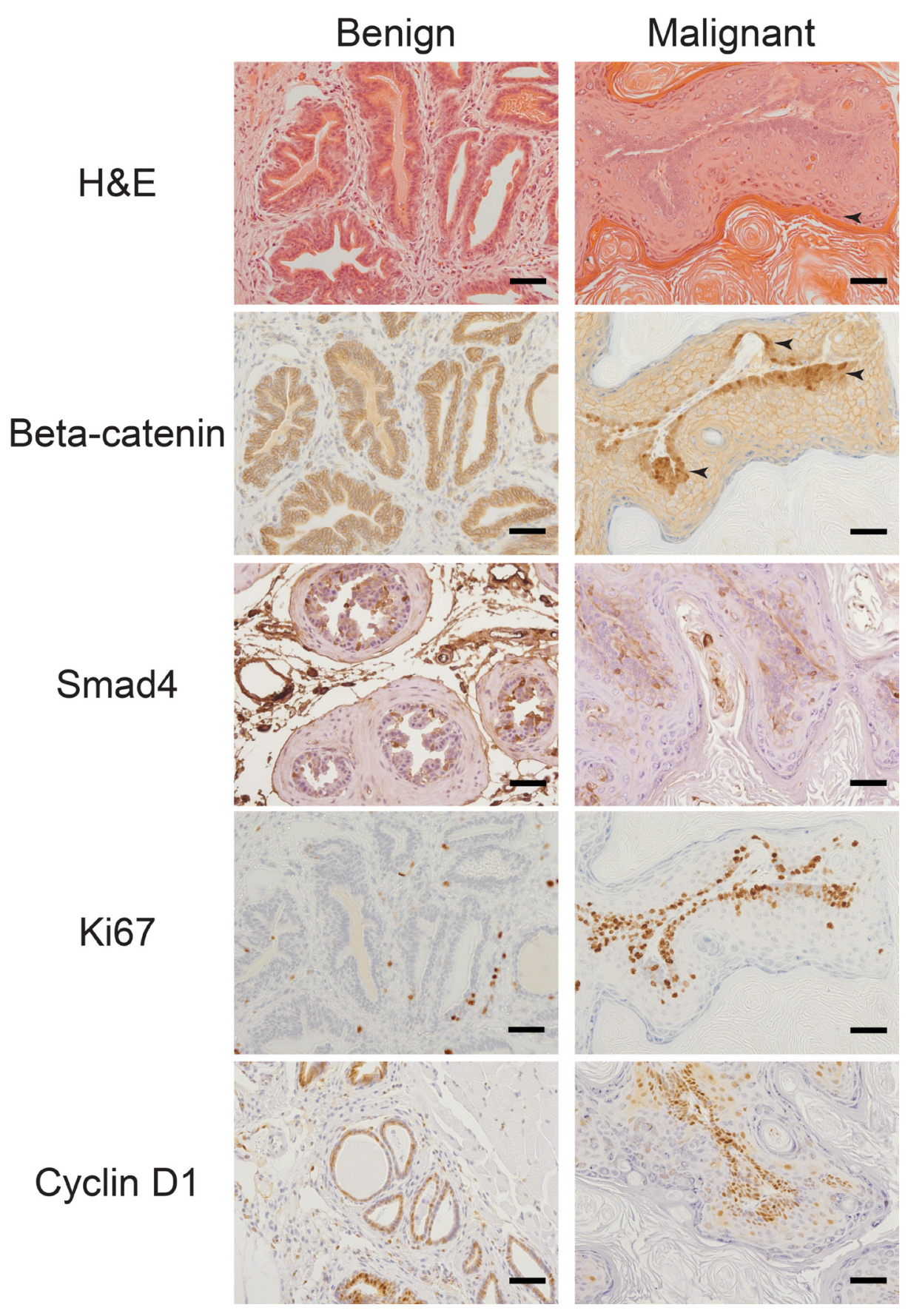

Figure 3: Gain of beta-catenin expression plus loss of Smad4 expression is associated with increased proliferation. Benign and malignant prostate tissue from $\mathrm{Apc}{ }^{\mathrm{cKO}}{ }^{-} \mathrm{Smad}_{4}{ }^{\mathrm{cKO}}$ mice were stained for hematoxylin and eosin (H\&E) and immuno-stained for beta-catenin, Smad4, Ki67, and cyclin D1. Arrows point to regions keratohyalin granule formation and loss of nuclei (H\&E stain) and regions of nuclear beta-catenin staining. Scale bars $=50 \mu \mathrm{m}$. 
resistant Nkx3.1-expressing cell (CARN) population, which behaves as a luminal-like stem cell [15]. We hypothesized that deleting Apc and Smad4 in this expanded stem-like population would cause aggressive carcinoma. However, we observed the opposite phenotype. Upon one cycle of castration and reintroduction of testosterone in $\mathrm{Apc}^{\text {cKo Smad4 }}{ }^{\text {cKO }}$ mice (Figure 7A), we saw eradication of the invasive phenotype, replaced with occasional evidence of high-grade prostate intraepithelial neoplasia (HGPIN) (Figure 7B). After two cycles (Figure 7B), there was no longer any evidence of neoplasia in any of the prostate tissue. In addition, $\beta$-catenin expression remained membranous, indicating inactive Wnt signaling, and Ki67 staining indicated normal proliferation levels (Figure 7D). This phenotype was observed in the BUGs as well (Supplementary Figure 2D). We performed IHC for AR on prostate tissue from the various hormone states of the mice (hormonally normal, castrated, and androgen cycled). As reported earlier in this work, AR is lost in hormonally normal, tamoxifen treated $\mathrm{Apc}^{\mathrm{cKO}} \mathrm{Smad} 4^{\mathrm{CKO}}$ prostate tissue

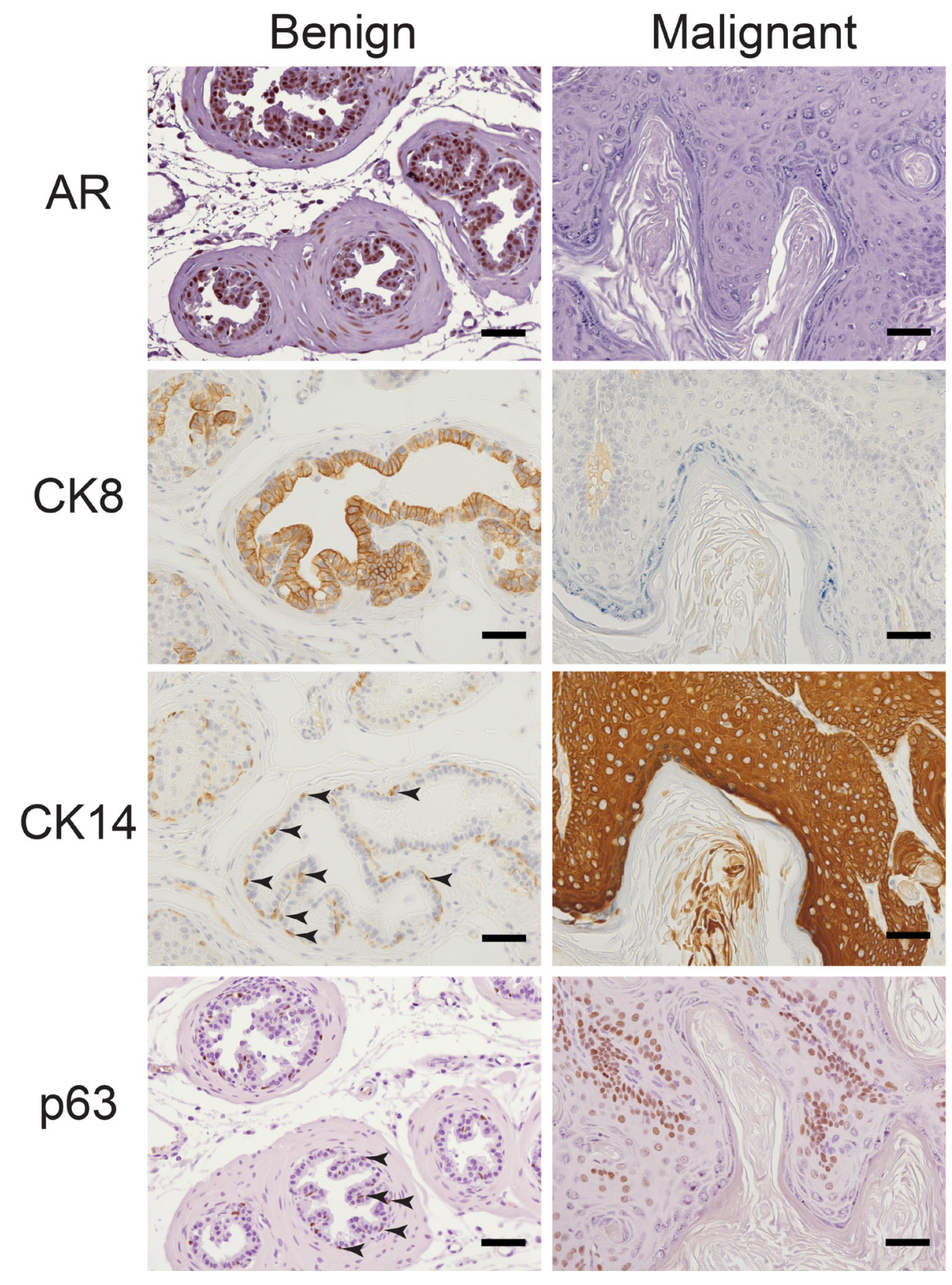

Figure 4: Concurrent loss of AR and luminal marker CK8 and expansion of basal markers CK14 and p63 in malignant tissue. Benign and malignant prostate tissue from $\mathrm{Apc}^{\mathrm{cKO}}{ }^{\mathrm{Smad}} 4^{\mathrm{cKO}}$ mice were immuno-stained for androgen receptor (AR), cytokeratin 8 (CK8), cytokeratin 14 (CK14), and p63. Arrows point to representative positively stained CK14 and p63 basal cells. Scale bars $=50 \mu \mathrm{m}$. 
(Supplementary Figure 1A). In castration resistant prostate tissue, we found strong AR staining in benign regions and loss of AR staining in malignant regions, suggesting that loss of AR is closely associated with malignancy in this model (Supplementary Figure 1B). Interestingly, AR staining appeared relatively normal in the androgen cycled $\mathrm{Apc}^{\mathrm{cKO}} \mathrm{Smad} 4^{\mathrm{cKO}}$ prostate tissue (Supplementary Figure 1C). In addition, when we previously stained for $\mathrm{AR}$ in $\mathrm{Apc} \mathrm{cKO}^{\mathrm{KO}}$ lesions, we saw not only presence of $\mathrm{AR}$, but an increase in AR staining [5]. This indicates that the combinatorial loss of both Apc and Smad4 produces the loss of AR phenotype.
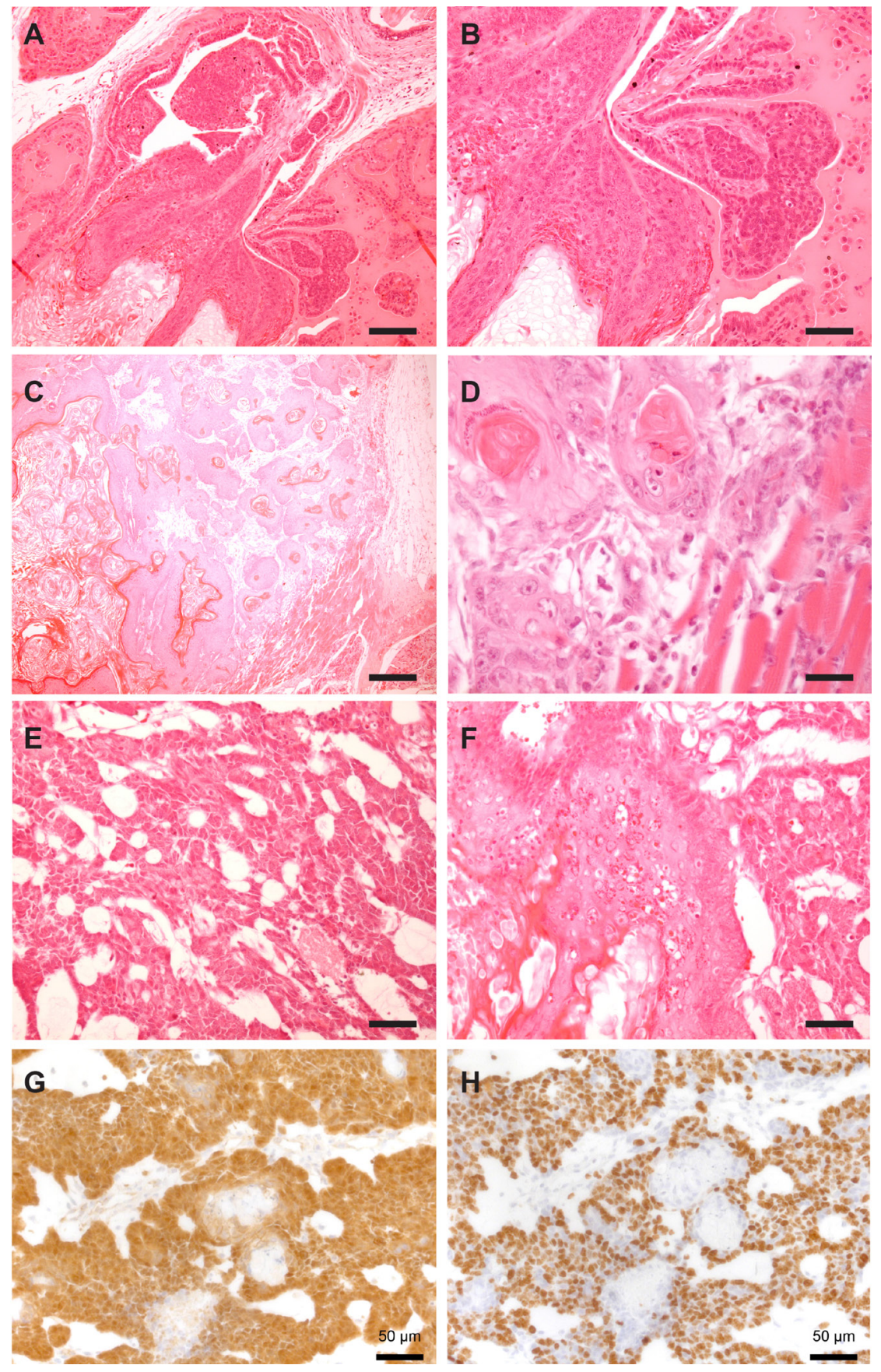

Figure 5: Mix of differentiation phenotypes in Apc ${ }^{\text {cKo }}$ Smad4 ${ }^{\text {cKo }}$ tumors. Representative hematoxylin and eosin staining of prostate tumors from Apc ${ }^{\mathrm{cKO}}$ Smad4 ${ }^{\mathrm{cKO}}$ mice. Squamous in situ carcinoma (A-B); scale bars $=100 \mu \mathrm{m}(\mathrm{A})$ and $200 \mu \mathrm{m}$ (B). Squamous carcinoma with muscular invasion $(\mathbf{C}-\mathbf{D})$; scale bars $=250 \mu \mathrm{m}(\mathrm{C})$ and $25 \mu \mathrm{m}(\mathrm{D})$. Basaloid carcinoma $(\mathbf{E})$; scale bar $=50 \mu \mathrm{m}$. Representative image of mixed basaloid and squamous cell carcinoma in the same region $(\mathbf{F})$; scale bar $=50 \mu \mathrm{m}$. Representative images of basaloid region of prostate tumor stained with beta-catenin $(\mathbf{G})$ and $\mathrm{Ki67}(\mathbf{H})$; scale bars $=50 \mu \mathrm{m}$. 


\section{DISCUSSION}

Multiple genetic pathways are involved in the tumorigenesis of the prostate $[3,18-21]$. Due to this heterogeneity - as well as the normal physiological differences between human and mouse prostates $[22,23]$ - it has been difficult to create a mouse model that fully recapitulates human prostate cancer progression. Many genetically engineered models have been made, each one representing some aspect of prostate cancer, and contributing to the library of knowledge on the effect of each gene(s) on prostate tumorigenesis and progression [22]. Using similar strategies, we have generated a novel mouse model of invasive prostate carcinoma, in which Apc and Smad4 have been deleted in a specific population of luminal cells.

In previous work, we have shown that Apc deletion in luminal prostate cells, using one of two different prostate-specific promoters to drive Cre expression (Probasin or Nkx3.1), is tumorigenic, but is not sufficient to cause invasive carcinoma or metastasis $[4,5]$. Others have shown similar results by activating a constitutive version of $\beta$-catenin using the same Cre drivers $[6,7]$. These data suggest that at least a second genetic hit is required to induce invasiveness or metastasis. This appears counterintuitive, as $\mathrm{Wnt} / \beta$-catenin activation in humans correlates with prostate cancer progression [2], though it is possible that other genetic hits are coincident in patients with up-regulated Wnt signaling.

We show for the first time within the prostate that loss of Apc and Smad4 act in concert to promote tumorigenesis and invasion. Apc loss by itself results in HGPIN, and Smad4 loss by itself results in no observable histological change. But when combined, large tumors form with extremely high levels of proliferation as well as invasive properties. Histological analysis of these tumors

A

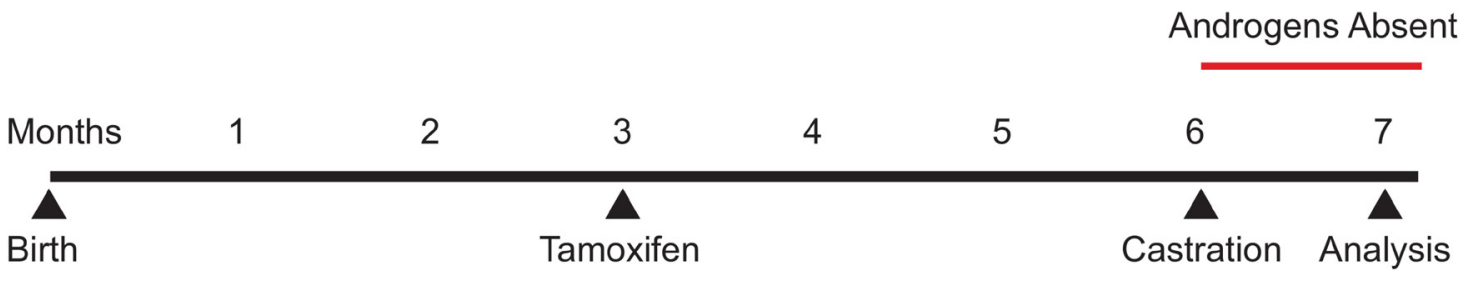

\section{Androgens Present}
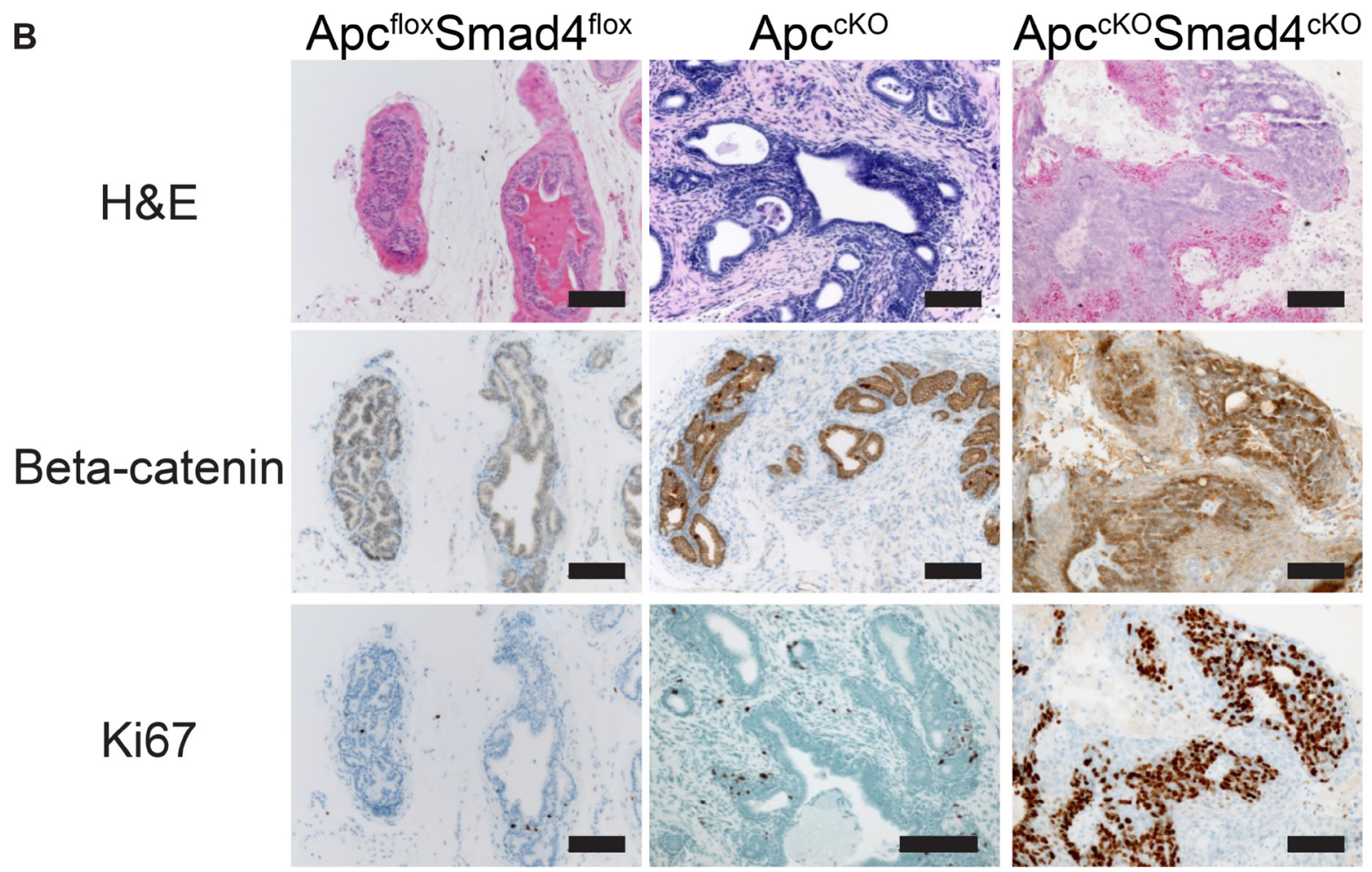

Figure 6: Tumors in Apc ${ }^{\text {cKo }}$ Smad4 ${ }^{\text {cKo }}$ mice are castration resistant. (A) Timeline of tamoxifen administration, castration, and sacrifice of control and experimental mice; and (B) representative images of prostate tissue from $\mathrm{Apc}^{\mathrm{flox}} \mathrm{Smad} 4^{\text {flox }}, \mathrm{Apc}^{\mathrm{cKO}}$, and $\mathrm{Apc}^{\mathrm{cKO}} \mathrm{Smad} 4{ }^{\mathrm{cKO}}$ mice were stained for hematoxylin and eosin (H\&E) and immuno-stained for beta-catenin and Ki67. Scale bars $=100 \mu \mathrm{m}$. 
A

\begin{tabular}{cccccccc} 
Months & 1 & 2 & 3 & 4 & 5 & 6 & 7 \\
\hline Birth & & $\mathbf{\Delta}$ & $\mathbf{A}$ & $\mathbf{A}$ & Tamoxifen & Castration Testosterone
\end{tabular}

\section{Androgens Present}

B

$A p c^{\text {flox }}$ Smad4 $4^{\text {flox }}$
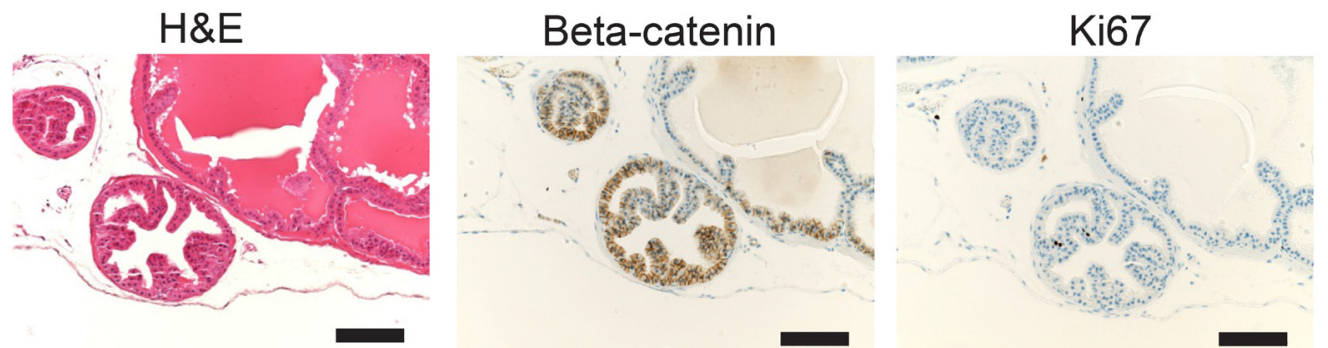

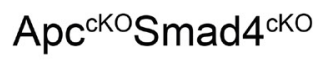
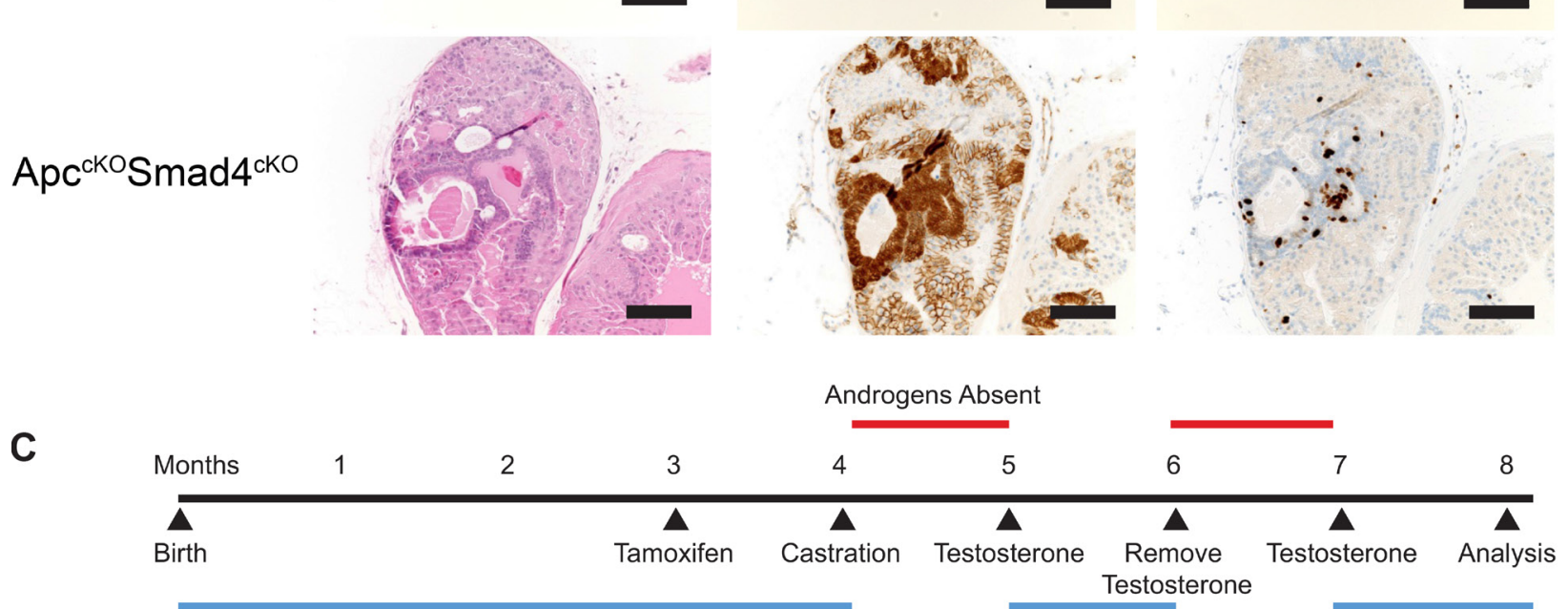

Androgens Present

$H \& E$

D

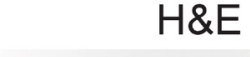

$A p c^{\text {flox }}$ Smad4 $4^{\text {flox }}$

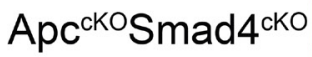

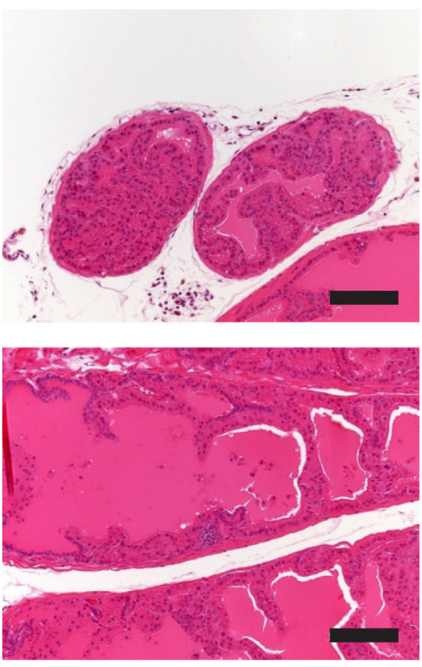

Beta-catenin

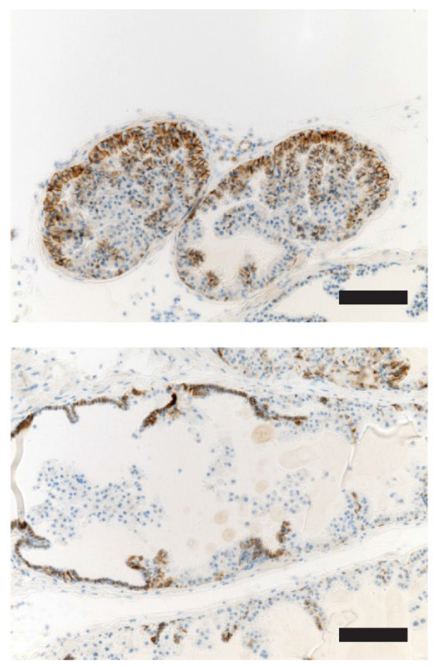

Ki67

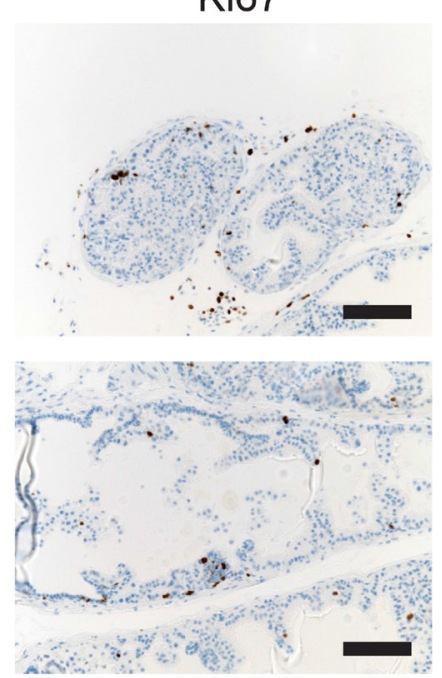

Figure 7: Loss of cancer phenotype after one or more rounds of androgen cycling. Timelines of one rounds of androgen cycling $(\mathbf{A})$ and two rounds of androgen cycling $(\mathbf{C})$ in control and experimental mice. Representative hematoxylin and eosin (H\&E), betacatenin, and Ki67 staining of prostate tissue from Apc ${ }^{\mathrm{flox}} \mathrm{Smad} 4^{\mathrm{Hlox}}$ and $\mathrm{Apc}{ }^{\mathrm{cKO} O} \mathrm{Smad} 4^{\mathrm{cKO}}$ mice $(\mathbf{B}$ and $\mathbf{D})$. Scale bars $=100 \mu \mathrm{m}$. 
revealed a range of differentiation, including basaloid and squamous differentiation, rare phenotypes in human prostate cancer patients. It has been suggested that Apc and Smad4 may act in concert in humans, and two separate microRNAs have been found to target Smad4 in addition to Wnt signaling antagonists secreted frizzled related protein 1 (sFRP1) or Dickkopf 3 (DKK3) [13, 24]. They showed that DKK3 reduced TOP-Flash luciferase activity, indicating that, at least in this context, DKK3 reduced Wnt activity. This suggests that the Apc ${ }^{\mathrm{cKO}} \mathrm{Smad} 4{ }^{\mathrm{cKO}}$ mouse model may have value in determining the mechanisms behind the rare sub-types (basaloid and squamous) of prostate cancer.

Similar to our previously published Apc deletion models [4, 5], we observed castration resistance of the primary tumors of $\mathrm{Apc}{ }^{\mathrm{cKO}} \mathrm{Smad} 44^{\mathrm{cKO}}$ mice if mice were castrated after tumor development. If mice were castrated prior to tumor development (in our model, prior to tamoxifen administration) tumors did not develop. These data indicate that $\mathrm{Apc}{ }^{\mathrm{cKO}} \mathrm{Smad} 4{ }^{\mathrm{cKO}}$ tumors rely on androgens for tumorigenesis, but once tumors develop, they grow in the absence of androgens. Wnt/ $\beta$-catenin signaling has also been linked to AR signaling, and may serve to promote tumorigenesis in the absence of AR signaling, supporting this theory [25-27].

One unexpected phenomenon we observed in the $\mathrm{Apc}{ }^{\mathrm{cKO}} \mathrm{Smad} 4{ }^{\mathrm{cKO}}$ model was the disappearance of tumors with androgen cycling (castration followed by re-introduction of testosterone). Androgen deprivation therapy (ADT) is a common treatment for metastatic prostate cancer, due to the dependence of the prostate and most prostate cancers on androgens. When patients develop castration resistant disease, their cancer is aggressive and incurable. One strategy that is currently in clinical trials is to administer supraphysiological amounts of testosterone following castration, in a similar hormone cycling manner that we employed. This strategy is known as rapid androgen cycling or bipolar androgen therapy [28-31].

While hormone depletion results in a high rate of apoptosis in prostate tumors, castration resistance eventually develops in response [28]. AR expression is elevated in response to castration via multiple mechanisms, including $A R$ gene amplification and mutation [32-35]. Exposure of AR-positive prostate cancer cells to supraphysiological concentrations of androgen results in growth inhibition [36, 37]. A high concentration of androgen leads to transient doublestranded DNA breaks via recruitment of topoisomerase II $\beta$ [38]. It has also been shown that AR plays a suppressive role in basal cell populations in the prostate, indicating that loss of AR may drive proliferation of a more basaloid phenotype [39]. Putting these ideas together, ADT plus supraphysiological androgen cycling seems to result in a delayed castration resistance, growth inhibition, and apoptosis due to DNA damage. While we observed a loss of $\mathrm{AR}$ in the malignant regions of the prostates (particularly the squamous regions) from $\mathrm{Apc}{ }^{\mathrm{cKO}} \mathrm{Smad} 4{ }^{\mathrm{cKO}}$ mice, we observed that there were still benign, ARexpressing regions remaining (Supplementary Figure 1B). In addition, we have previously shown an increase of AR expression in response to Apc depletion alone [5]. We hypothesize that the combination of up-regulation of AR expression early in the model with hormone cycling resulted in loss of the tumor phenotype in our model.

The Apc ${ }^{\mathrm{cKO} S m a d 4}{ }^{\mathrm{cKO}}$ model will provide new genetic information for prostate cancer development, particularly in the basaloid and squamous differentiated cancers, and will serve as a model of castration resistance and potentially for a sub-population of prostate cancer patients whose tumors involve some combination of aberrant Wnt, TGF $\beta$, and BMP signaling.

\section{MATERIALS AND METHODS}

\section{Generation of mice}

All animals were used in protocols that were reviewed and approved by the Institutional Animal Care and Use Committee of the Van Andel Research Institute. $A p c^{\text {flox }}$ [4], Smad4 ${ }^{\text {flox }}$ [16], and $N k x 3.1^{\text {CreERT }}$ [15], have all been previously described. To generate $\mathrm{Apc}^{\mathrm{cKO}}$ mice, we crossed $N k x 3.1^{\mathrm{CreERT}}$ heterozygous mice (transgenic allele plus wild-type allele, or $\mathrm{tg} /+$ ) with mice homozygous for a floxed allele of $A p c$ (flox/flox) to generate $N k x 3 \cdot 1^{\mathrm{CreERTtg} /+} ; A p c^{\text {flox/+ }}$ mice [5]. We then crossed these mice together to generate homozygous mutant $N k x 3.1^{\mathrm{CreERTtg} /+} ; A p c^{\text {flox/flox }}$ mice. Mice wild-type for Cre $\left(N k x 3.1^{\mathrm{CreERT}+/+} ; A p c^{\text {flox/flox }}\right)$ were subjected to the same experimental conditions as the mutant mice and were used as controls. To generate $\mathrm{Ap}{ }^{\mathrm{cKO}} \mathrm{Smad} 44^{\mathrm{cKO}}$ mice, we crossed $N k x 3.1^{\mathrm{CreERTtg} /+} ; A p c^{\text {flox/flox }}$ mice to Smad4 $4^{\text {flox } /}$ flox mice to generate $N k x 3.1^{\mathrm{CreERTtg} /+} ; A p c^{\text {flox/+ }} ; \operatorname{Smad} 4^{\mathrm{flox} /+}$ mice. We then crossed these mice together to generate homozygous mutant $N k x 3 \cdot 1^{\mathrm{CreERTtg} /+} ; A p c^{\text {flox/flox }}: \operatorname{Smad} 4^{\text {flox/ }}$ flox mice. Cre-negative mice that were homozygous for Apc and Smad4 floxed alleles $\left(N k x 3.1^{\mathrm{CreERT}+/+} ; A p c^{\text {flox/ }}\right.$ flox:Smad4 flox/flox which we refer to as Apc $c^{\text {flox }}$ Smad4 ${ }^{\text {flox }}$ mice) were used as negative controls. For genotyping of all mice, DNA was prepared from tail biopsies using sodium hydroxide extraction [40], and PCRbased strategies were then used to genotype these mice $[41,42]$. All mice used in this study were of mixed genetic background (see Supplementary Table 1).

\section{Tamoxifen administration}

Tamoxifen (Sigma T5648) was dissolved at $20 \mathrm{mg} / \mathrm{mL}$ in a 9:1 mixture of corn oil and ethanol the same day of administration to mice. This tamoxifen mixture $(500 \mu \mathrm{L})$ was administered to mice via oral gavage once per day for 2 consecutive days. 


\section{Allele-specific and quantitative reverse transcriptase PCR}

To confirm that exon 14 of $A p c$ had been deleted in the prostate of mutant $\mathrm{Apc}^{\mathrm{cKO}}$ mice, DNA was isolated from whole prostate lobes using the Qiagen DNeasy kit (69504), and PCR amplification was done to amplify wildtype, floxed, or deleted alleles using previously described primers [42]. For quantitative RT-PCR, RNA was removed from mouse prostate using Trizol, centrifuged with chloroform to separate out the aqueous RNA phase, and then RNA was ethanol-precipitated and purified using the Qiagen RNeasy kit (74034). TaqMan ${ }^{\circledR}$ primers and probes for Axin2 and Smad4 RT-PCR were purchased and used to perform qPCR in triplicate.

\section{Histology and immunohistochemistry}

Hematoxylin (Sigma MHS16) and eosin (Sigma HT110216) staining and immunohistochemistry was performed on tissues fixed in 10\% neutral buffered formalin (NBF) for 24-48 hours, embedded in paraffin, and sectioned at $5 \mu \mathrm{m}$ thickness. Immunohistochemical staining was optimized using the Discovery XT System (Ventana, Tuscon, AZ). The following antibodies were used for immunohistochemistry: $\beta$-catenin (polyclonal, Cell Signaling Technology, Danvers, MA), Ki67 (SP6, Spring Biosciences, Pleasanton, CA), cyclin D1 (SP4, Thermo Fisher Scientific, Halethorpe, MD), AR (EPR1535(2), Abcam, Cambridge, MA), cytokeratin 14 (polyclonal, BioLegend, San Diego, CA), cytokeratin 8 (polyclonal, Spring Biosciences, Pleasanton, CA), p63 (D2K8X, Cell Signaling Technology, Danvers, MA), and Smad4 (B-8, Santa Cruz Biotechnology, Dallas, TX).

\section{Hormone ELISA}

Upon dissection of mice, approximately $500 \mu \mathrm{L}$ of blood was removed via intracardiac puncture, mixed with $5 \mu \mathrm{L}$ of $0.5 \mathrm{M}$ EDTA, $\mathrm{pH} 8.0$, and then centrifuged at $6,000 \times \mathrm{g}$ for 6 minutes. Approximately $200 \mu \mathrm{L}$ of serum was removed from the top layer and stored at $-80^{\circ} \mathrm{C}$. This serum was used in the Cayman Chemical testosterone EIA kit or estradiol EIA kit to determine hormone levels. The student's $T$-test was used to assess potential statistical differences between groups.

\section{Castration and testosterone re-administration}

Surgical castration was performed by making a single $1 \mathrm{~cm}$ longitudinal incision into the skin and peritoneum anterior to the preputial gland. The epididymal fat pad, vas deferens, and both testes were removed via cauterization. The peritoneal incision was sutured shut, and the skin was closed with wound clips. Wound clips were removed 14 days post-surgery. Post-castration mice showed no signs of infection. Testosterone (Sigma T1500) was administered to mice via semipermeable silastic tubes subcutaneously inserted into the dorsal mid-trunk region of the mice. This method has been previously described [43]. These tubes were removed when required for testosterone removal.

\section{Nuance microscopy quantification}

Images were taken on a Nuance microscope, and were un-mixed for brown stain and blue (hematoxylin) stain. Identical thresholds were used to quantify the number of positively stained pixels for either the IHC stain (e.g. Ki67) or hematoxylin. Hematoxylin-positive nuclei represented the denominator, and IHC-stained nuclei represented the numerator. The student's $T$-test was used to assess potential statistical differences between groups.

\section{Authors' contributions}

KCV: Performed all mouse experiments and data collection; performed majority of data analysis; wrote and submitted the manuscript; AMDM: Provided crucial pathological analysis of mouse tumor tissue; edited the manuscript; BOW: Provided critical experimental ideology, mentorship, and funding; data analysis; edited the manuscript.

\section{ACKNOWLEDGMENTS}

We thank Dr. Ronald DePinho for providing the Smad4 ${ }^{\text {flox }}$ mice. We thank Drs. Wade Bushman, Cindy Miranti, and Matt Steensma for advice and discussion. We thank the VARI vivarium and histology cores - particularly Lisa Turner - for their assistance and expertise. BOW and $\mathrm{KCV}$ were supported by internal funds from the Van Andel Research Institute. KCV was funded by the Van Andel Institute Graduate School.

\section{CONFLICTS OF INTEREST}

The authors have no financial conflicts of interest to disclose.

\section{REFERENCES}

1. Siegel RL, Miller KD, Jemal A. Cancer statistics, 2016. CA Cancer J Clin. 2016; 66:7-30.

2. Chen G, Shukeir N, Potti A, Sircar K, Aprikian A, Goltzman D, Rabbani SA. Up-regulation of Wnt-1 and betacatenin production in patients with advanced metastatic prostate carcinoma: potential pathogenetic and prognostic implications. Cancer. 2004; 101:1345-1356.

3. Robinson D, Van Allen EM, Wu YM, Schultz N, Lonigro RJ, Mosquera JM, Montgomery B, Taplin ME, Pritchard CC, Attard G, Beltran H, Abida W, Bradley RK, 
et al. Integrative clinical genomics of advanced prostate cancer. Cell. 2015; 161:1215-1228.

4. Bruxvoort KJ, Charbonneau HM, Giambernardi TA, Goolsby JC, Qian CN, Zylstra CR, Robinson DR, RoyBurman P, Shaw AK, Buckner-Berghuis BD, Sigler RE, Resau JH, Sullivan R, et al. Inactivation of Apc in the mouse prostate causes prostate carcinoma. Cancer Res. 2007; 67:2490-2496.

5. Valkenburg KC, Yu X, De Marzo AM, Spiering TJ, Matusik RJ, Williams BO. Activation of Wnt/beta-catenin signaling in a subpopulation of murine prostate luminal epithelial cells induces high grade prostate intraepithelial neoplasia. Prostate. 2014; 74:1506-1520.

6. Yu X, Wang Y, DeGraff DJ, Wills ML, Matusik RJ. Wnt/ beta-catenin activation promotes prostate tumor progression in a mouse model. Oncogene. 2011; 30:1868-1879.

7. Yu X, Wang Y, Jiang M, Bierie B, Roy-Burman $\mathrm{P}$, Shen MM, Taketo MM, Wills M, Matusik RJ. Activation of beta-Catenin in mouse prostate causes HGPIN and continuous prostate growth after castration. Prostate. 2009; 69:249-262.

8. Pearson HB, Phesse TJ, Clarke AR. K-ras and Wnt signaling synergize to accelerate prostate tumorigenesis in the mouse. Cancer Res. 2009; 69:94-101.

9. Aitchison AA, Veerakumarasivam A, Vias M, Kumar R, Hamdy FC, Neal DE, Mills IG. Promoter methylation correlates with reduced Smad4 expression in advanced prostate cancer. Prostate. 2008; 68:661-674.

10. Ding Z, Wu CJ, Chu GC, Xiao Y, Ho D, Zhang J, Perry SR, Labrot ES, Wu X, Lis R, Hoshida Y, Hiller D, Hu B, et al. SMAD4-dependent barrier constrains prostate cancer growth and metastatic progression. Nature. 2011; 470:269-273.

11. Horvath LG, Henshall SM, Kench JG, Turner JJ, Golovsky D, Brenner PC, O’Neill GF, Kooner R, Stricker PD, Grygiel JJ, Sutherland RL. Loss of BMP2, Smad8, and Smad4 expression in prostate cancer progression. Prostate. 2004; 59:234-242.

12. Ding Z, Wu CJ, Jaskelioff M, Ivanova E, Kost-Alimova M, Protopopov A, Chu GC, Wang G, Lu X, Labrot ES, Hu J, Wang W, Xiao Y, et al. Telomerase reactivation following telomere dysfunction yields murine prostate tumors with bone metastases. Cell. 2012; 148:896-907.

13. Hirata H, Hinoda Y, Shahryari V, Deng G, Tanaka Y, Tabatabai ZL, Dahiya R. Genistein downregulates oncomiR-1260b and upregulates sFRP1 and Smad4 via demethylation and histone modification in prostate cancer cells. Br J Cancer. 2014; 110:1645-54.

14. Li X, Placencio V, Iturregui JM, Uwamariya C, SharifAfshar AR, Koyama T, Hayward SW, Bhowmick NA. Prostate tumor progression is mediated by a paracrine TGFbeta/Wnt3a signaling axis. Oncogene. 2008; 27:7118-7130.

15. Wang X, Kruithof-de Julio M, Economides KD, Walker D, Yu H, Halili MV, Hu YP, Price SM, Abate-Shen C, Shen MM. A luminal epithelial stem cell that is a cell of origin for prostate cancer. Nature. 2009; 461:495-500.
16. Bardeesy N, Cheng KH, Berger JH, Chu GC, Pahler J, Olson P, Hezel AF, Horner J, Lauwers GY, Hanahan D, DePinho RA. Smad4 is dispensable for normal pancreas development yet critical in progression and tumor biology of pancreas cancer. Genes Dev. 2006; 20:3130-3146.

17. Bhatia-Gaur R, Donjacour AA, Sciavolino PJ, Kim M, Desai N, Young P, Norton CR, Gridley T, Cardiff RD, Cunha GR, Abate-Shen C, Shen MM. Roles for Nkx3.1 in prostate development and cancer. Genes Dev. 1999; 13:966-977.

18. Barbieri CE, Bangma CH, Bjartell A, Catto JW, Culig Z, Gronberg H, Luo J, Visakorpi T, Rubin MA. The mutational landscape of prostate cancer. Eur Urol. 2013; 64:567-576.

19. Wyatt AW, Mo F, Wang K, McConeghy B, Brahmbhatt S, Jong L, Mitchell DM, Johnston RL, Haegert A, Li E, Liew J, Yeung J, Shrestha R, et al. Heterogeneity in the inter-tumor transcriptome of high risk prostate cancer. Genome Biol. 2014; 15:426.

20. Wyatt AW, Mo F, Wang Y, Collins CC. The diverse heterogeneity of molecular alterations in prostate cancer identified through next-generation sequencing. Asian J Androl. 2013; 15:301-308.

21. Al Olama AA, Kote-Jarai Z, Berndt SI, Conti DV, Schumacher F, Han Y, Benlloch S, Hazelett DJ, Wang Z, Saunders E, Leongamornlert D, Lindstrom S, JugurnauthLittle S, et al, and Breast and Prostate Cancer Cohort Consortium (BPC3), and PRACTICAL (Prostate Cancer Association Group to Investigate Cancer-Associated Alterations in the Genome) Consortium, and COGS (Collaborative Oncological Gene-environment Study) Consortium, and GAME-ON/ELLIPSE Consortium. A meta-analysis of 87,040 individuals identifies 23 new susceptibility loci for prostate cancer. Nat Genet. 2014; 46:1103-1109.

22. Valkenburg KC, Williams BO. Mouse models of prostate cancer. Prostate Cancer. 2011; 2011:895238.

23. Valkenburg KC, Pienta KJ. Drug discovery in prostate cancer mouse models. Expert Opin Drug Discov. 2015; 10:1011-24.

24. Ueno K, Hirata H, Shahryari V, Deng G, Tanaka Y, Tabatabai ZL, Hinoda Y, Dahiya R. microRNA-183 is an oncogene targeting Dkk-3 and SMAD4 in prostate cancer. Br J Cancer. 2013; 108:1659-1667.

25. Cronauer MV, Schulz WA, Ackermann R, Burchardt M. Effects of WNT/beta-catenin pathway activation on signaling through T-cell factor and androgen receptor in prostate cancer cell lines. Int J Oncol. 2005; 26:1033-1040.

26. Mulholland DJ, Cheng H, Reid K, Rennie PS, Nelson CC. The androgen receptor can promote beta-catenin nuclear translocation independently of adenomatous polyposis coli. J Biol Chem. 2002; 277:17933-17943.

27. Song LN, Herrell R, Byers S, Shah S, Wilson EM, Gelmann EP. Beta-catenin binds to the activation function 
2 region of the androgen receptor and modulates the effects of the N-terminal domain and TIF2 on ligand-dependent transcription. Mol Cell Biol. 2003; 23:1674-1687.

28. Feltquate D, Nordquist L, Eicher C, Morris M, Smaletz O, Slovin S, Curley T, Wilton A, Fleisher M, Heller G, Scher HI. Rapid androgen cycling as treatment for patients with prostate cancer. Clin Cancer Res. 2006; 12:7414-7421.

29. Rathkopf D, Carducci MA, Morris MJ, Slovin SF, Eisenberger MA, Pili R, Denmeade SR, Kelsen M, Curley T, Halter M, Collins C, Fleisher M, Heller G, et al. Phase II trial of docetaxel with rapid androgen cycling for progressive noncastrate prostate cancer. J Clin Oncol. 2008; 26:2959-2965.

30. Denmeade SR, Isaacs JT. Bipolar androgen therapy: the rationale for rapid cycling of supraphysiologic androgen/ ablation in men with castration resistant prostate cancer. Prostate. 2010; 70:1600-1607.

31. Schweizer MT, Antonarakis ES, Wang H, Ajiboye AS, Spitz A, Cao H, Luo J, Haffner MC, Yegnasubramanian S, Carducci MA, Eisenberger MA, Isaacs JT, Denmeade SR. Effect of bipolar androgen therapy for asymptomatic men with castration-resistant prostate cancer: results from a pilot clinical study. Sci Transl Med. 2015; 7:269ra262.

32. Gregory CW, He B, Johnson RT, Ford OH, Mohler JL, French FS, Wilson EM. A mechanism for androgen receptor-mediated prostate cancer recurrence after androgen deprivation therapy. Cancer Res. 2001; 61:4315-4319.

33. Montgomery RB, Mostaghel EA, Vessella R, Hess DL, Kalhorn TF, Higano CS, True LD, Nelson PS. Maintenance of intratumoral androgens in metastatic prostate cancer: a mechanism for castration-resistant tumor growth. Cancer Res. 2008; 68:4447-4454.

34. Nacusi LP, Tindall DJ. Androgen receptor abnormalities in castration-recurrent prostate cancer. Expert Rev Endocrinol Metab. 2009; 4:417-422.

35. Stanbrough M, Bubley GJ, Ross K, Golub TR, Rubin MA, Penning TM, Febbo PG, Balk SP. Increased expression of genes converting adrenal androgens to testosterone in androgen-independent prostate cancer. Cancer Res. 2006; 66:2815-2825.
36. Isaacs JT, D'Antonio JM, Chen S, Antony L, Dalrymple SP, Ndikuyeze GH, Luo J, Denmeade SR. Adaptive autoregulation of androgen receptor provides a paradigm shifting rationale for bipolar androgen therapy (BAT) for castrate resistant human prostate cancer. Prostate. 2012; 72:1491-1505.

37. Umekita Y, Hiipakka RA, Kokontis JM, Liao S. Human prostate tumor growth in athymic mice: inhibition by androgens and stimulation by finasteride. Proc Natl Acad Sci U S A. 1996; 93:11802-11807.

38. Haffner MC, Aryee MJ, Toubaji A, Esopi DM, Albadine R, Gurel B, Isaacs WB, Bova GS, Liu W, Xu J, Meeker AK, Netto G, De Marzo AM, et al. Androgen-induced TOP2Bmediated double-strand breaks and prostate cancer gene rearrangements. Nat Genet. 2010; 42:668-675.

39. Lee SO, Tian J, Huang CK, Ma Z, Lai KP, Hsiao H, Jiang M, Yeh S, Chang C. Suppressor role of androgen receptor in proliferation of prostate basal epithelial and progenitor cells. J Endocrinol. 2012; 213:173-182.

40. Truett GE, Heeger P, Mynatt RL, Truett AA, Walker JA, Warman ML. Preparation of PCR-quality mouse genomic DNA with hot sodium hydroxide and tris (HotSHOT). Biotechniques. 2000; 29:52, 54.

41. Wu X, Wu J, Huang J, Powell WC, Zhang J, Matusik RJ, Sangiorgi FO, Maxson RE, Sucov HM, Roy-Burman P. Generation of a prostate epithelial cell-specific Cre transgenic mouse model for tissue-specific gene ablation. Mech Dev. 2001; 101:61-69.

42. Qian CN, Knol J, Igarashi P, Lin F, Zylstra U, Teh BT, Williams BO. Cystic renal neoplasia following conditional inactivation of apc in mouse renal tubular epithelium. J Biol Chem. 2005; 280:3938-3945.

43. Hu WY, Shi GB, Lam HM, Hu DP, Ho SM, Madueke IC, Kajdacsy-Balla A, Prins GS. Estrogen-initiated transformation of prostate epithelium derived from normal human prostate stem-progenitor cells. Endocrinology. 2011; 152:2150-2163. 